\title{
Inactivation and Damage of Histamine-Forming Bacteria by Treatment with High Hydrostatic Pressure
}

\author{
Yi-Chen Lee ${ }^{1, *}$, Yung-Hsiang Tsai ${ }^{1}$, Shao-Lan Chen ${ }^{1}$, Hsien-Feng Kung ${ }^{2}$, Osamu Arakawa ${ }^{3}$ (D) \\ and Cheng-I Wei ${ }^{4}$ \\ 1 Department of Seafood Science, National Kaohsiung University of Science and Technology, Kaohsiung 811, \\ Taiwan; yhtsai01@seed.net.tw (Y.-H.T.); ap92425@gmail.com (S.-L.C.) \\ 2 Department of Pharmacy, Tajen University, 907 Pingtung, Taiwan; khfeng@mail.tajen.edu.tw \\ 3 Graduate School of Fisheries and Environmental Sciences, Nagasaki University, 852-8521 Nagasaki, Japan; \\ arakawa@nagasaki-u.ac.jp \\ 4 Department of Nutrition and Food Science, University of Maryland, College Park, MD 20742, USA; \\ wei@umd.edu \\ * Correspondence: lionlee@nkust.edu.tw; Tel.: +886-7-3617141-23613; Fax: +886-7-3640634
}

Received: 30 January 2020; Accepted: 24 February 2020; Published: 2 March 2020

\begin{abstract}
The inactivation and damage of histamine-forming bacteria (HFB), Enterobacter aerogenes and Staphylococcus capitis, in a $0.1 \mathrm{M}$ potassium phosphate buffer ( $\mathrm{pH} 6.8$ ) and marlin meat slurry by high hydrostatic pressure (HHP) treatments were studied using viability measurement and scanning electron microscopy (SEM). HHP treatments showed first order destruction kinetics to E. aerogenes and $S$. capitis during the pressure holding period. HFB in marlin meat slurry had higher D values and were more resistant to HHP treatments than in phosphate buffer. In phosphate buffer, E. aerogenes had higher D values than S. capitis at $>380 \mathrm{MPa}$ of pressure, whereas the reverse trend was noticed at lower pressures (<380 MPa). In marlin meat slurry, S. capitis had a higher D value than E. aerogenes at the same treatment pressure, indicating that $S$. capitis was more resistant to HHP treatment. To our knowledge, this is the first report to demonstrate that HHP can be used to inactivate HFB, E. aerogenes, and S. capitis, by causing disruption to bacterial cell membrane and cell wall as demonstrated by SEM micrographs.
\end{abstract}

Keywords: high hydrostatic pressure; histamine-forming bacteria; inactivation; SEM

\section{Introduction}

Histamine fish poisoning, or scombroid poisoning, is an allergy-like form of food poisoning resulting from the consumption of mishandled scombroid fish that contains high contents of histamine [1]. Histamine is generated mainly by the decarboxylation of histidine in fish muscle through the actions of histidine decarboxylases of histamine-forming bacteria (HFB) that are present in the seafood. HFBs have been isolated from scombroid fish and other seafood products, as well as fermented foods such as wine, sausage, and cheese [2]. Two different types of histidine decarboxylase have been distinguished in these bacteria: Pyruvoyl-dependent enzymes and pyridoxal-5'-phosphate-dependent enzymes [3]. The pyruvoyl-dependent enzymes are encountered in Gram-positive bacteria such as lactic acid bacteria and Staphylococcus spp., producing histamine in fermented products including wine, cheese, douchi, mustard pickle, and fish sauce [4,5]. On the contrary, the pyridoxal-5'-phosphate-dependent enzymes are identified in Gram-negative enteric bacteria such as Enterobacter aerogenes, Raoultella orithinolytica, and Morganella morganii, producing histamine in the fish $[5,6]$. 
High hydrostatic pressure (HHP) is a nonthermal technology for food pasteurization and preservation [7]. In a commercial setting, HHP was used at a pressure above $300 \mathrm{MPa}$ to kill spoilage and pathogenic microorganisms for shelf-life extension and safety improvement of jams, fruit juices, guacamole, meats, dairy and egg products, and seafood [8,9]. The usage of HHP treatment to preserve the freshness of food was also shown to not affect some of the food quality characteristics such as the color, natural flavor, and nutrients $[9,10]$. However, HHP technology can have some disadvantages on the quality of fish including color changes with higher $L^{*}$ values associated with higher opacity, harder textures, and lipid oxidation [11,12]. HHP treatment was reported to be capable of killing Listeria monocytogenes, Escherichia coli, and Vibrio parahaemolyticus through morphological damages to both the internal and external structures [13,14]. A treatment at a pressure of $>300 \mathrm{MPa}$ can cause irreversible denaturation of enzymes and proteins to affect the integrity of the cell membrane, lowering protein biosynthesis and inhibit protein repairs, and ultimately resulting in cell membrane rupture, excretion of internal substances, and bacterial death [14,15].

HHP treatments can successfully control bacteria, but there are few data of inactivation kinetics on bacteria, especially concerning bacterial species and medium effects. In food processing, D (decimal reduction time) -value is the most frequently used kinetic parameter. Since only limited information was available on the inactivation effect and morphological damage of HFBs by HHP treatment, the aim of this study was to find out the inactivation kinetics of HHP processing on HFB, S. capitis, and E. aerogenes, in a $0.1 \mathrm{M}$ phosphate buffer ( $\mathrm{pH}$ 6.8) and marlin meat slurry, and to evaluate whether morphological damages occurred in HHP-treated HFB cells.

\section{Materials and Methods}

\subsection{Bacterial Culture Preparation}

Stock cultures of E. aerogenes and S. capitis were isolated from marlin meat [16] and dried milkfish [17], respectively. Briefly, both histamine-forming isolates were picked from differential agar plates (histamine-forming bacterium isolation agar) and identified by amplifying and sequencing approximately $1400 \mathrm{bp}$ of the $16 \mathrm{~S}$ ribosomal DNA (rDNA) [16,17]. The cultures were maintained in our laboratory on Trypticase Soy Agar (Difco Becton-Dickinson Co., Sparks, MD, USA) at $4{ }^{\circ} \mathrm{C}$.

\subsection{Preparation of E. aerogenes and S. capitis in Phosphate Buffer and Marlin Meat Slurry}

One loopful of E. aerogenes or S. capitis was inoculated into the Trypticase Soy Broth (TSB) tube $(5 \mathrm{~mL})$ and incubated at $35^{\circ} \mathrm{C}$ for $12 \mathrm{~h}$; then $100 \mu \mathrm{L}$ aliquot of the bacterial culture was added to $100 \mathrm{~mL}$ sterile TSB medium at $35^{\circ} \mathrm{C}$ for $24 \mathrm{~h}$. The cultured broth was centrifuged at $8000 \times \mathrm{g}$ for $15 \mathrm{~min}$ at $4{ }^{\circ} \mathrm{C}$ and the bacterial pellet was washed and resuspended in $0.05 \mathrm{M}$ potassium dihydrogen phosphate buffer ( $\mathrm{pH}$ 7.0). The bacterial suspension was then adjusted to a concentration of $10^{9} \mathrm{CFU} / \mathrm{mL}$.

Fresh marlin flesh was purchased from a local market in Kaohsiung City, Taiwan and transported in ice to the laboratory immediately. After washing with a 75\% ethanol solution for 1 min and rinsing with sterile water, the flesh was ground to mince in a sterile food homogenizer. The fish mince was then blended with $0.1 \%$ peptone water $(1: 4 ; \mathrm{w} / \mathrm{w})$ for $2 \mathrm{~min}$ in a blender (Omni International, Waterbury, CT, USA). Both the sterile potassium phosphate buffer $(0.1 \mathrm{M}, \mathrm{pH} 6.8,99 \mathrm{~mL})$ and the marlin meat slurry $(99 \mathrm{~mL})$ were inoculated with $1 \mathrm{~mL}$ of HFB inoculum $\left(10^{9} \mathrm{CFU} / \mathrm{mL}\right)$ to get at $10^{7} \mathrm{CFU} / \mathrm{mL}$ as the final concentration. The tested samples were added to sterile vacuum bags in 10-mL portions, vacuum packaged and heat-sealed, and then subject to HHP treatments immediately.

\subsection{High Hydrostatic Pressure Treatment}

Test bags in triplicate were treated with a laboratory model of high pressure processing system (BaoTou KeFa, High Pressure Technology, Co. Ltd., Baotou, China) at 200 to $500 \mathrm{MPa}$ for 0 to $10 \mathrm{~min}$ at room temperature $\left(25^{\circ} \mathrm{C}\right)$. This high pressure processing system having a 6.2-L chamber can be operating at up to $600 \mathrm{MPa}$ at a pressure increase rate of approximately $300 \mathrm{MPa} / \mathrm{min}$ and the release 
times of less than $20 \mathrm{~s}$ at all pressures. Water was used as a pressure transmission medium in this study, and the reported pressurization times did not include the time for pressure increase and release. An untreated bag placed in ice water at ambient pressure $(0.1 \mathrm{MPa})$ served as a control. Samples subject to pressure treatment were stored in ice water and immediately used for bacterial counting and SEM analyses.

\subsection{Enumeration of HFB Surviving Cells and Decimal Reduction Time}

Both the HHP treated and nontreated bacterial suspensions in phosphate buffer or fish slurry were 10 -fold serially diluted in a sterile phosphate buffer $(0.05 \mathrm{M}, \mathrm{pH} 7.0)$. Aliquots $(1.0 \mathrm{~mL})$ of the diluents were mixed in petri dishes with $15 \mathrm{~mL}$ TSA (Difco) at $45-50{ }^{\circ} \mathrm{C}$. After the agar medium was solidified in a laminar flow hood, the plates were transferred to an incubator and incubated at $30^{\circ} \mathrm{C}$ for 24-48 h. Bacterial colonies numbers on the plates were counted. Data from triplicate samples were presented as mean \pm standard deviation.

The linear first order reaction was used as follows to determine the pressure destruction kinetics of HFB during the pressure-hold time phase with log numbers of survivors:

$$
\log \left(N / N_{0}\right)=-1 / D \times t
$$

where $N_{0}$ is the initial number of HFB in untreated samples, $N$ is the surviving number of HFB after pressure treatment for time $\mathrm{t}(\mathrm{min})$. The $\mathrm{D}$-value or decimal reduction time is the treatment time at any given pressure causing $90 \%$ reduction of the HFB population, i.e., resulting in one logarithm reduction of the microbial population. D-value was obtained by the negative reciprocal slope of the $\log \left(N / N_{0}\right)$ vs. time.

The decimal logarithm of D-values vs. pressure was plotted to determine the pressure sensitivity of the D-values.

\subsection{Scanning Electron Microscopy (SEM) Analysis}

HFB cells in a $0.1 \mathrm{M}$ phosphate buffer ( $\mathrm{pH}$ 6.8) were harvested from pressure-treated (500 MPa for $10 \mathrm{~min}$ ) and nontreated suspensions via centrifugation at $5000 \mathrm{rpm}$ for $20 \mathrm{~min}$. After two washes with phosphate buffer, the pellets were resuspended in $1 \mathrm{~mL}$ of phosphate buffer and then filtered through Millipore membranes ( $0.22 \mu \mathrm{m}$ MF-Millipore, GSWP; Millipore Corp., Billerica, MA, USA). Cells on the filters were fixed with $10 \mathrm{~mL}$ of $1.5 \%$ glutaraldehyde/ $0.1 \mathrm{M}$ phosphate buffer ( $\mathrm{pH} 6.8$ ) and left overnight for drying at $4{ }^{\circ} \mathrm{C}$. After the cells on the membranes were washed three times with phosphate buffer for $10 \mathrm{~min}$, they were post-fixed for $90 \mathrm{~min}$ in $1 \%$ osmium tetroxide $\left(\mathrm{OsO}_{4}\right)$ and then rinsed with phosphate buffer twice (10 min per rinse). The cells on the membranes were then dehydrated in a series of $10 \mathrm{~mL}$ ethanol solutions (35\%, 50\%, $60 \%, 70 \%, 85 \%, 90 \%, 95 \%, 100 \%$, and $100 \%$ ethanol, 15 min each), immersed in isopentyl acetate and finally in carbon dioxide medium for critical point drying using a critical point dryer (HCP-2, Hitachi Koki Co., Ltd., Ibaragi, Japan). The dried membranes were then mounted on scanning electron microscope stubs, sputter-coated with a thin film of gold-palladium, and then observed by the SEM (S4700, Hitachi Koki Co., Ltd., Ibaragi, Japan) operating at $15 \mathrm{kV}$ voltage. SEM photomicrographs were taken from different regions of the same dried specimen.

\section{Results and Discussion}

\subsection{Inactivation Kinetics of HHP Treatment on Histamine-Forming Bacteria in Phosphate Buffer}

Figure 1 shows the survival curves of E. aerogenes and S. capitis in phosphate buffer following HHP treatment at 200-500 MPa for up to $10 \mathrm{~min}$. Both the treatment pressure and the holding time influenced the destruction of the bacteria. The sharper survival curves at higher pressures than at lower pressures indicated that the destruction rate was greater at higher pressures. The first order 
model fits the destruction kinetics of HHP treatment on HFB during the hold period, indicating that pressure destruction of E. aerogenes and S. capitis complied with the semi-logarithmic model. From the survival curves, the D-values could be calculated and used for comparison of microbial resistance to HHP treatment or the effectiveness of such treatment on microbial destruction. The computed D-values and R squared parameters of E. aerogenes and S. capitis in phosphate buffer showed that $S$. capitis had higher D-values (13.4 and $4.65 \mathrm{~min}$, respectively), and therefore more resistant, than E. aerogenes (3.82 and $3.08 \mathrm{~min}$, respectively) when treated with HHP at 200 and $300 \mathrm{MPa}$ (Table 1). However, as the pressure level was elevated to $400 \mathrm{MPa}$, the difference in the D-values diminished, with E. aerogenes having a value of $2.42 \mathrm{~min}$ and S. capitis of $2.35 \mathrm{~min}$. At $500 \mathrm{MPa}$, the D-values were 0.92 and $0.22 \mathrm{~min}$ for E. aerogenes and S. capitis, respectively.

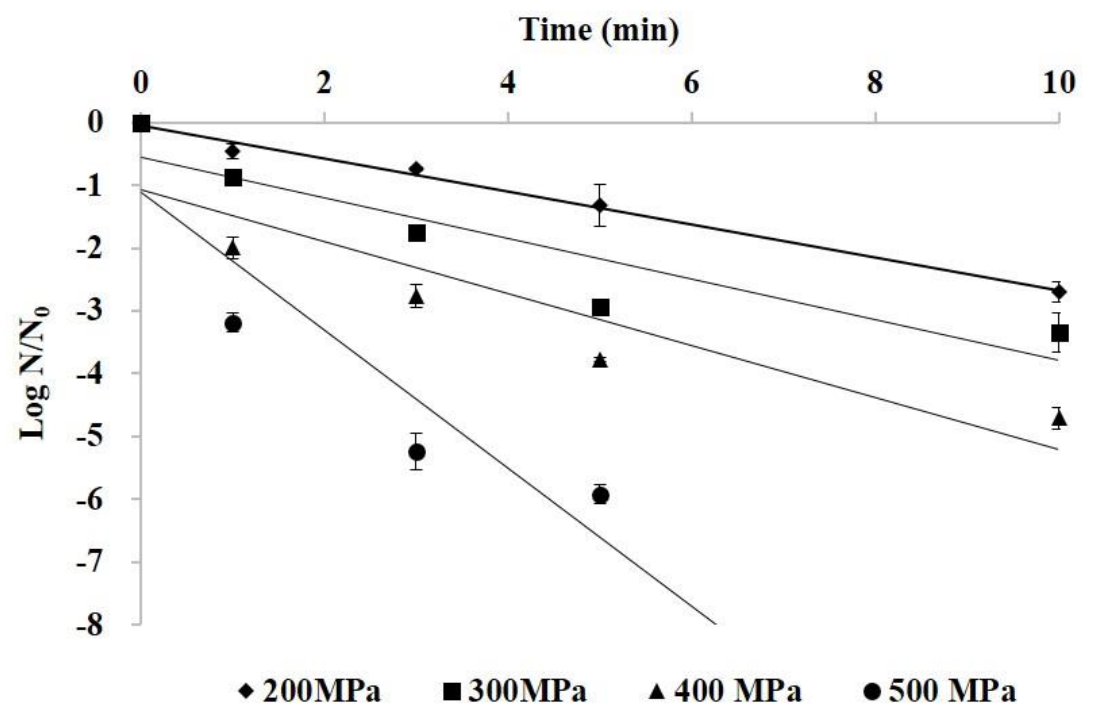

(A)

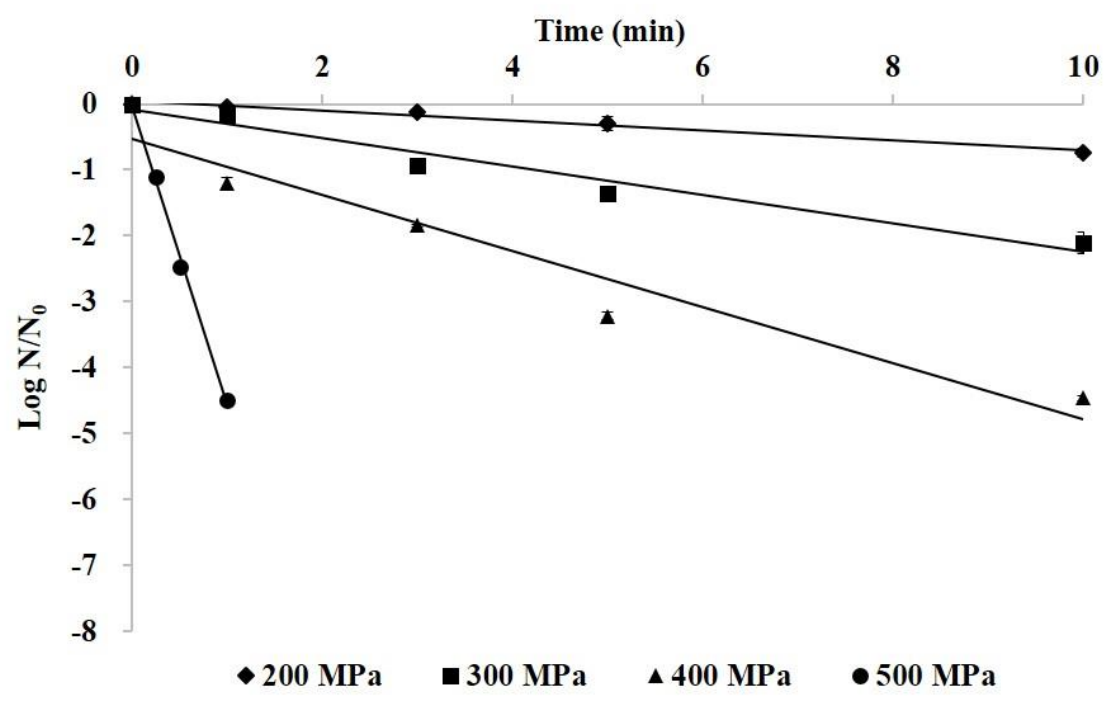

Figure 1. The survival curves of E. aerogenes (A) and S. capitis (B) in phosphate buffer by high hydrostatic pressure (HHP) treatment at 200-500 MPa for up to $10 \mathrm{~min}$.

The HHP decimal reduction time curves as obtained by charting the decimal logarithm of D-values vs. pressure showed a crossover pressure point of $380 \mathrm{MPa}$ for the two bacterial species, indicating that E. aerogenes in phosphate buffer was more resistant than S. capitis to HHP destruction at pressures $>380 \mathrm{MPa}$ (Figure 2). This also means that it would require shorter holding times to destroy E. aerogenes than S. capitis at lower treatment pressures of $<380 \mathrm{MPa}$. 
Table 1. The inactivation kinetics of high hydrostatic pressure on E. aerogenes and S. capitis in phosphate buffer and marlin meat slurry.

\begin{tabular}{cccc}
\hline Pressure (MPa) & Slope & D-Value (min) ${ }^{\mathbf{a}}$ & $\mathbf{R}^{\mathbf{2}}$ \\
\hline $\begin{array}{c}\text { In phosphate buffer } \\
\text { E. aerogenes }\end{array}$ & & \\
200 & -0.26 & 3.82 & 0.98 \\
300 & -0.33 & 3.08 & 0.86 \\
400 & -0.41 & 2.42 & 0.83 \\
500 & -1.10 & 0.92 & 0.85 \\
S. capitis & & & \\
200 & -0.07 & 13.4 & 0.98 \\
300 & -0.22 & 4.65 & 0.96 \\
400 & -0.43 & 2.35 & 0.94 \\
500 & -4.52 & 0.22 & 0.99 \\
\hline In marlin meat slurry & & & \\
E. aerogenes & & & \\
200 & -0.14 & 7.00 & 0.95 \\
300 & -0.24 & 4.11 & 0.86 \\
400 & -0.31 & 3.26 & 0.85 \\
500 & -0.33 & 2.99 & 0.83 \\
200 & & & \\
300 & -0.06 & 16.0 & 0.86 \\
400 & -0.09 & 10.9 & 0.85 \\
500 & -0.17 & 5.87 & 0.85 \\
S. capitis & -0.36 & 2.82 & 0.89 \\
\hline
\end{tabular}

${ }^{\text {a }} \mathrm{D}$ : Decimal reduction time (min); $\mathrm{R}^{2}$ : Regression coefficient.

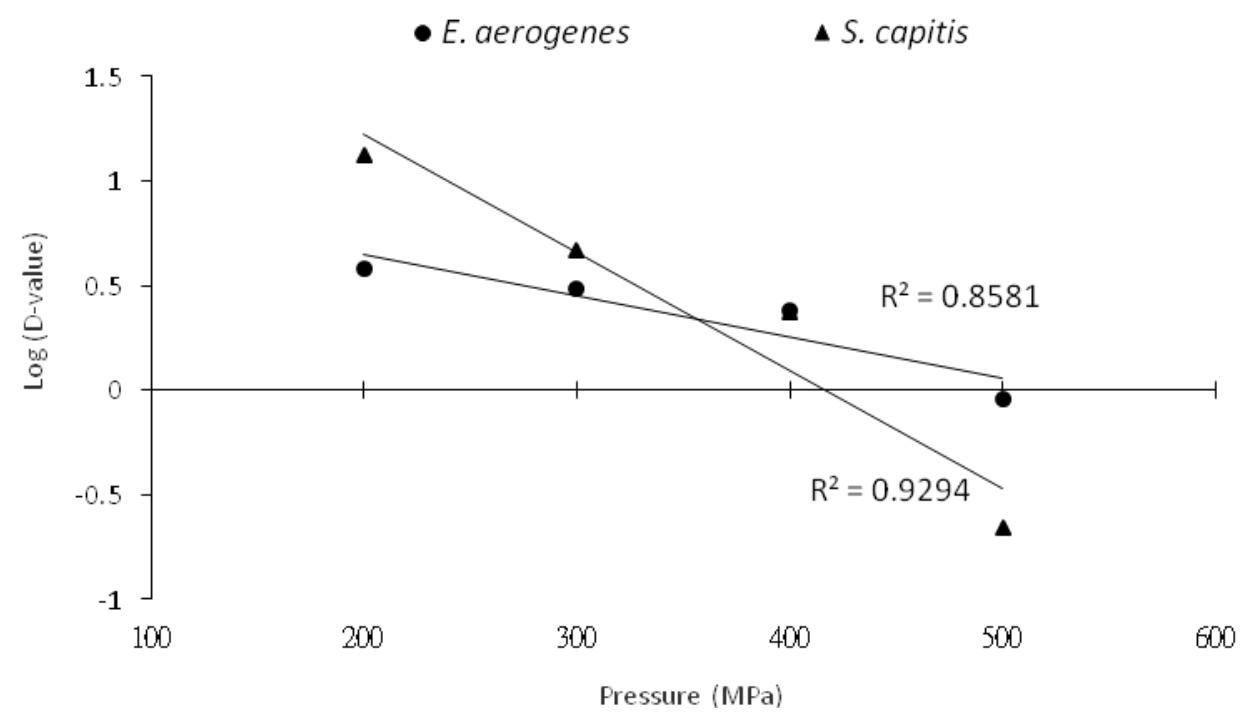

Figure 2. HHP decimal reduction time curves for E. aerogenes and S. capitis in phosphate buffer.

The inactivation of Escherichia coli in saline solution by HHP treatments was followed by first order kinetics, with D-values of $25.9 \mathrm{~min}$ at $200 \mathrm{MPa}, 8.0 \mathrm{~min}$ at $250 \mathrm{MPa}, 2.5 \mathrm{~min}$ at $300 \mathrm{MPa}$, and $0.8 \mathrm{~min}$ at $350 \mathrm{MPa}$ [18]. Patterson et al. [19] demonstrated that E. coli in phosphate buffer had a D-value of 13 min at $700 \mathrm{MPa}$; and Furukawa et al. [20] showed a calculated D-value of $143 \mathrm{~min}$ at $100 \mathrm{MPa}$ for E. coli in tryptic soy broth. Both the test medium and the bacterial strains used for HHP treatment contributed to differences in the D-values of treated E. coli or Listeria monocytogenes [21]. Tassou et al. [22] reported the inactivation of $S$. aureus in phosphate buffer, with D-values of 21.1,17.3, 7.0, 1.6, and 0.6 min for HHP treatments at 300, 350, 400, 450, and $500 \mathrm{MPa}$, respectively. However, the D-value of S. aureus at $350 \mathrm{MPa}$ was about $10 \mathrm{~min}$ in phosphate buffer [23]. 


\subsection{Inactivation Kinetics of HHP Treatment on Histamine-Forming Bacteria in Marlin Meat Slurry}

The inactivation kinetics during HHP treatment (200-500 MPa for 0-10 min) of E. aerogenes and S. capitis in marlin meat slurry are shown in Figure 3. The logarithm of the surviving E. aerogenes and S. capitis in the meat slurry linearly decreased with the increase of pressure time, indicating that the HHP inactivation followed adequately first order kinetics. The computed D-values of HHP-treated bacteria in meat slurry showed a higher D-value at lower treatment pressure for both bacterial species, and the treated S. capitis at 200, 300, and $400 \mathrm{MPa}$ had a higher D-value than E. aerogenes (Table 1). However, at the treatment pressure of $500 \mathrm{MPa}$, the treated E. aerogenes had a D-value of $2.99 \mathrm{~min}$ and the $2.82 \mathrm{~min}$ for S. capitis.

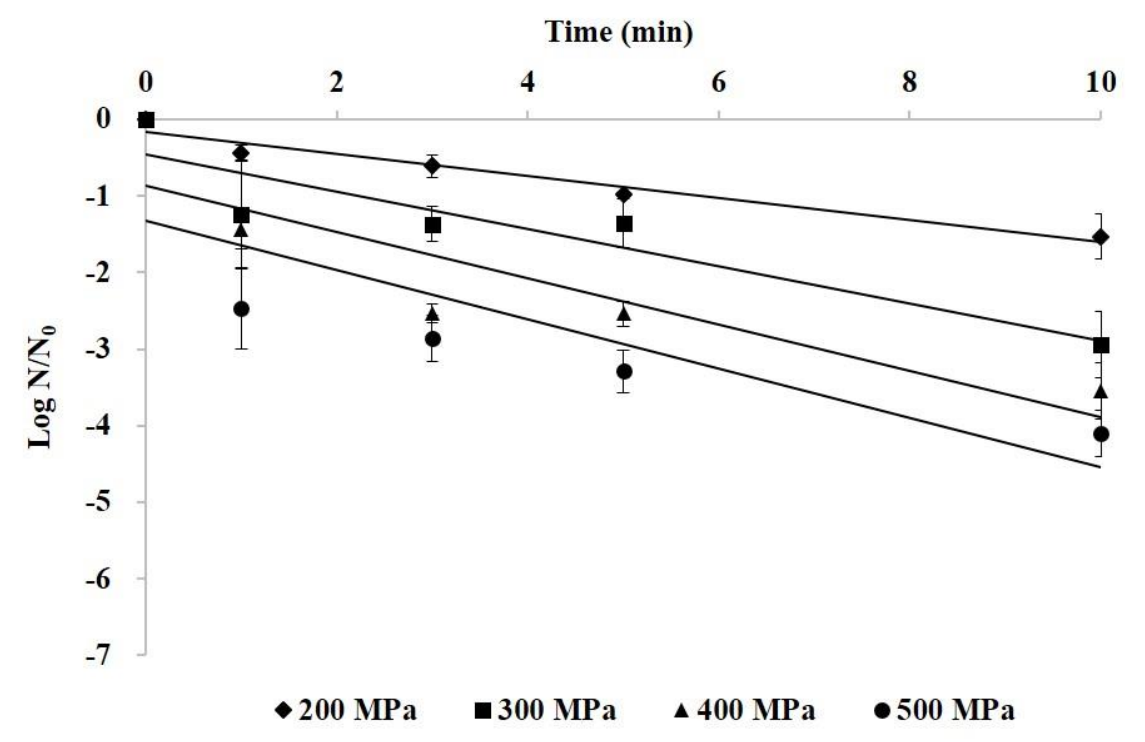

(A)

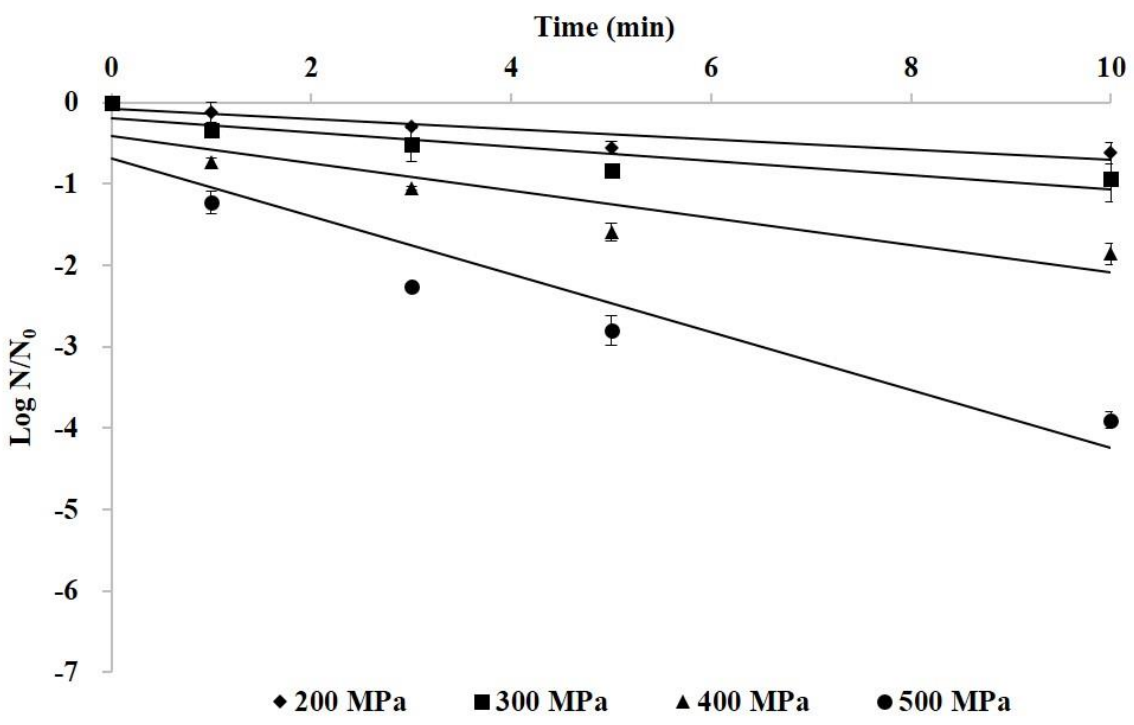

Figure 3. The survival curves of E. aerogenes (A) and S. capitis (B) in marlin meat slurry by HHP treatment at 200-500 MPa for up to $10 \mathrm{~min}$.

The HHP decimal reduction time curves for both bacterial species showed a crossover pressure point at $500 \mathrm{MPa}$ (Figure 4). Thus, S. capitis, in general, had a higher D-value than E. aerogenes in marlin meat slurry because it was more resistant to pressure treatment than E. aerogenes. Food processing using a pressure treatment at $<500 \mathrm{MPa}$ would take a longer holding time to carry out the same damaging effect to the contaminated S. capitis as to E. aerogenes. 


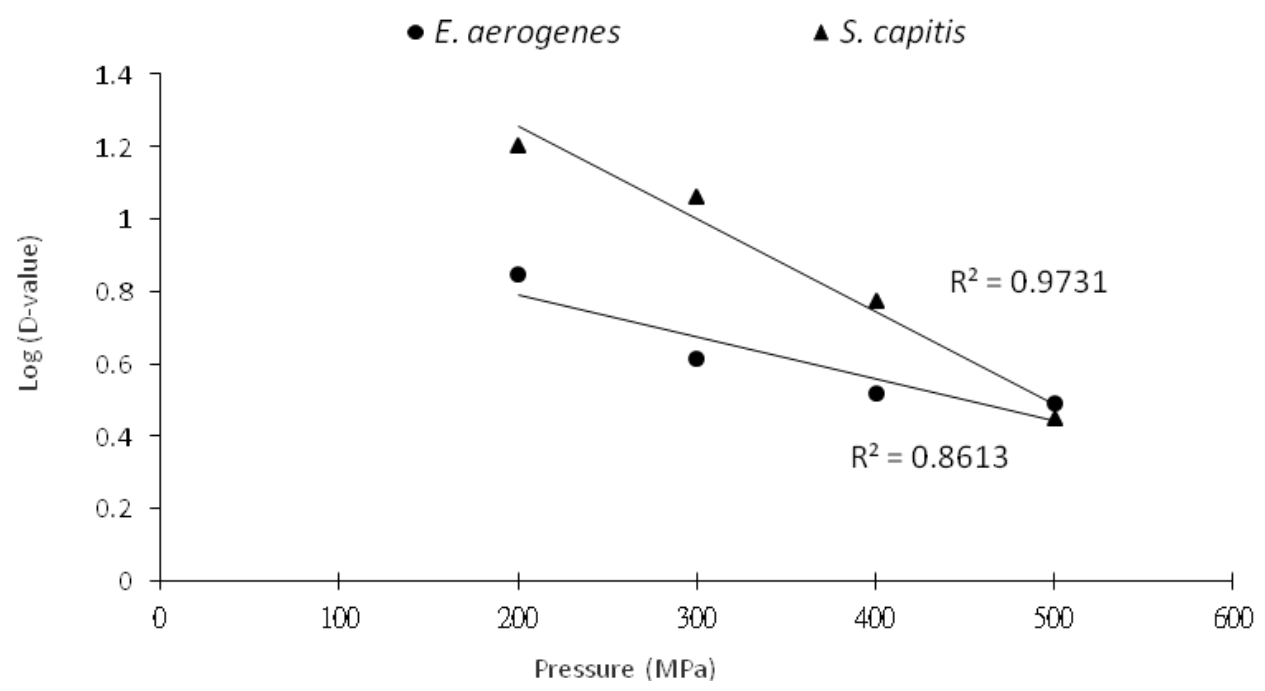

Figure 4. HHP decimal reduction time curves for E. aerogenes and S. capitis in marlin meat slurry.

Hoover et al. [24] reported that Gram-positive bacteria are in general regarded to be more resistant than Gram-negative bacteria to HHP treatment. In addition, the small and spherical bacteria were generally regarded as more tolerant to HHP treatment than large and rod-shaped bacteria [15]. Therefore, Gram-positive and cocci bacteria are more resistant to HHP treatment than Gram-negative and rod-shaped bacteria. The results shown in this study exhibited a similar finding that the $G(+)$ S. capitis in marlin meat slurry was more resistant to high pressure treatment than the $\mathrm{G}(-)$ E. aerogenes.

In this study, both the S. capitis and E. aerogenes in marlin meat slurry had higher D-values than those in phosphate buffer for all the pressure treatment conditions (Table 1), indicating that the HFB were more resistant to pressure treatment in marlin meat slurry than in phosphate buffer. Many intrinsic and environmental parameters, especially the nature of the suspension medium, influence the resistance of microorganisms to pressure treatment. Simpson and Gilmour [25] reported that bacteria existing in nutrient-rich media had great survival ability to high pressure treatment because the media contained nutrients that are essential for repairing or substances that may provide protection against damage. Microorganisms in food systems were more resistant to HHP treatment than in buffer solution, while such resistance ability to pressure treatment increased as the water activity decreased [26]. Fish matrix was reported to have higher protective effect to spoilage bacteria than the phosphate buffer at pressures below $550 \mathrm{MPa}$ [27]. Patterson [28] also stated that some food constituents such as lipids, proteins, carbohydrates, and salt can have a protective effect for the microbial cells. Therefore, the HPB cells in marlin meat slurry are more protected against HHP treatment due to protein and lipid contents.

\subsection{SEM Micrographs of Histamine-Forming Bacteria after Exposure to HHP Treatment}

Figures 5 and 6 are the SEM micrographs of E. aerogenes and S. capitis in phosphate buffer following $\mathrm{HHP}$ treatment at $500 \mathrm{MPa}$ for $10 \mathrm{~min}$, respectively. Compared to the untreated cells (Figure $5 \mathrm{a}, \mathrm{b}$ and Figure $6 a, b)$, damages of cellular envelopes and intracellular structures occurred with E. aerogenes and S. capitis after HHP treatment (Figure $5 c, d$ and Figure $6 c, d$, respectively). At lower magnification (Figures $5 \mathrm{c}$ and $6 \mathrm{c}$ ), the treated bacteria showed some roughness features on the cell wall, the occurrence of pimples-like damages, and swellings that resulted in some cells being compressed and other shattered. Similar findings were also reported previously with the treated Listeria cells at $400 \mathrm{MPa}$ for $10 \mathrm{~min}$ and V. parahaemolyticus at $300 \mathrm{MPa}$ for $10 \mathrm{~min}$ [14,29]. Closer observations of the treated bacterial cells in Figures $5 \mathrm{~d}$ and $6 \mathrm{~d}$ showed the presence of broken cell walls and perforation, and the loss of plasma membrane and cytoplasm content. 


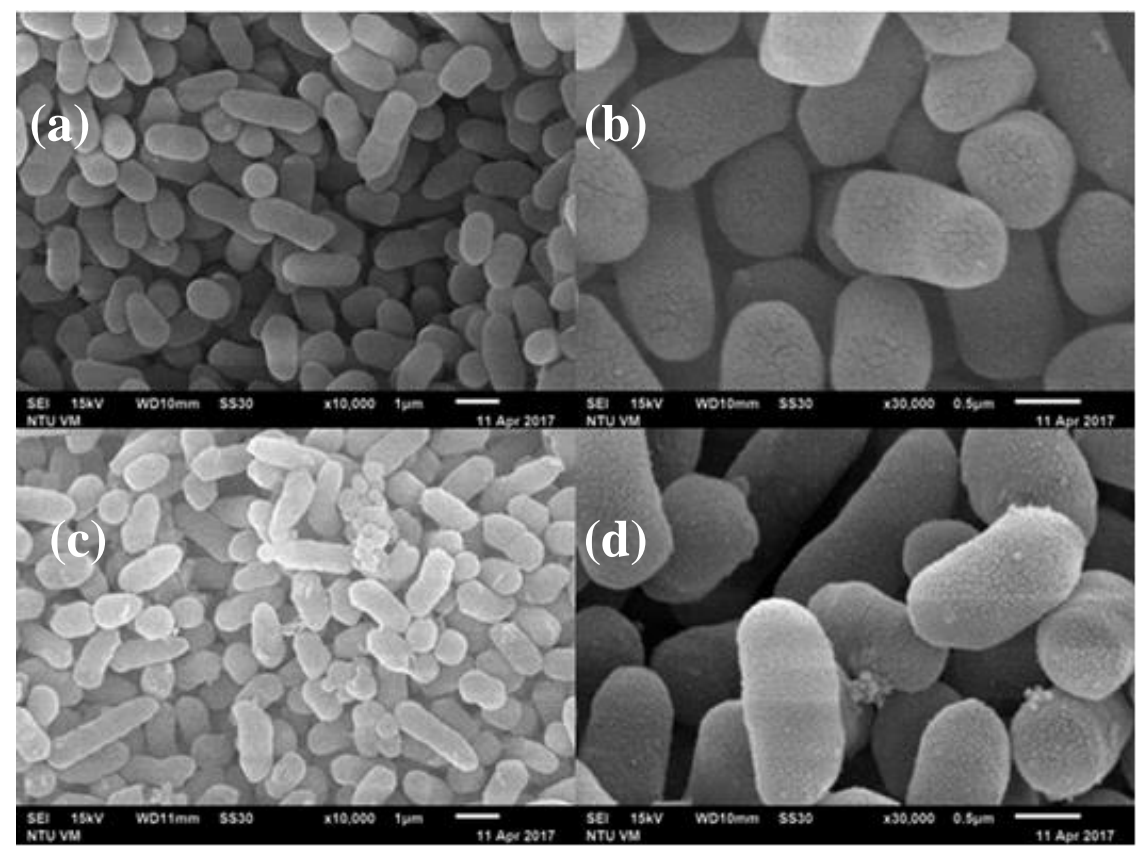

Figure 5. SEM micrographs of Enterobacter aerogenes cells in phosphate buffer. (a) and (b) Untreated cells; (c) and (d), cells treated with $500 \mathrm{MPa}$ for $10 \mathrm{~min}$.

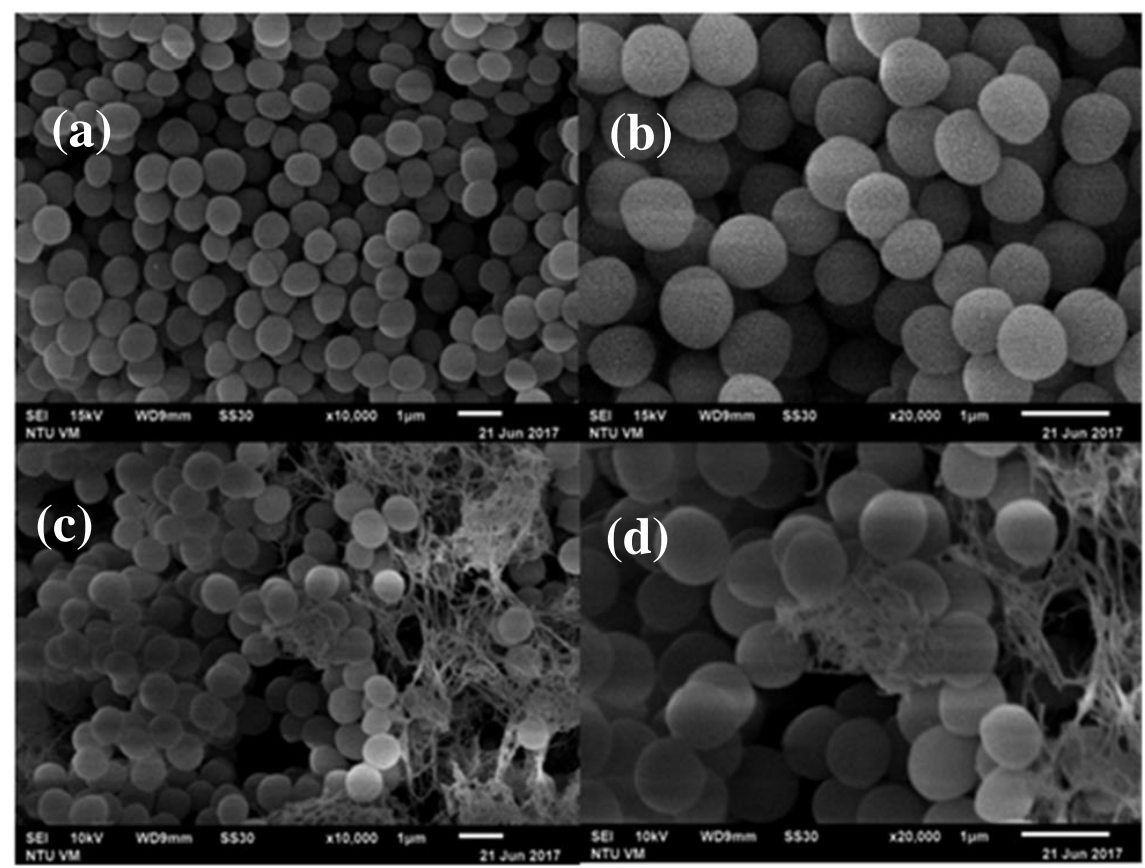

Figure 6. SEM micrographs of Staphylococcus capitis cells in phosphate buffer. (a) and (b) Untreated cells; (c) and (d), cells treated with $500 \mathrm{MPa}$ for $10 \mathrm{~min}$.

Ritz et al. [30] employed SEM to show the presence of bud scars on cellular surface after pressure treatment of L. monocytogenes, and the loss of membrane integrity in most of the bacterial cells. Mackey et al. [31], by using electron micrographs, showed that bacterial cells of different genera had different resistance to high pressure treatment, and pressure treatment led to changes in cellular morphology and intracellular enzyme activity. SEM examination of pressure-treated S. aureus and E. coli O157:H7 at 200 and $400 \mathrm{MPa}$ showed increases in volume and view area of the microorganisms [29], possibly attributed to phase transition of phospholipid bilayer and denaturation of bound proteins on the cell membrane due to HHP treatment. Marx et al. [32] showed perforation damages on the 
cell membrane and cell wall, and scars on cells surface of Saccharmyces cerevisiae in apple juice after HHP treatment at $600 \mathrm{MPa}$ for $7 \mathrm{~min}$. Recently, Wang et al. [14] indicated that the cause of damage to bacterial membrane by HHP treatment is one of the most important underlying mechanisms of HHP inactivation of bacterial pathogens. All these studies supported the findings that HHP treatment of bacterial cells causes damages to cell membrane permeability, loss of membrane integrity, cellular swelling, and eventually cell death. The results of this study suggest that the damage site of E. aerogenes and $S$. capitis by HHP treatment could be the cell membrane or cell wall.

\section{Conclusions}

This study, with the objective of investigating the inactivation of HFB using HHP treatment, showed that HHP can be applied to inactivate histamine-forming bacteria S. capitis and E. aerogenes by damaging the cell wall and cell membrane. The results showed that HFB in marlin meat slurry were more resistant to HHP treatment than in phosphate buffer. In marlin meat slurry, S. capitis was more resistant to HHP treatment than E. aerogenes.

Author Contributions: Conceptualization, Y.-C.L., Y.-H.T., and S.-L.C.; methodology, Y.-C.L., Y.-H.T., and S.-L.C.; analysis, S.-L.C. and H.-F.K.; data curation, Y.-C.L., H.-F.K., and S.-L.C.; writing-original draft preparation, Y.-C.L., O.A., and S.-L.C.; writing-review and editing, Y.-C.L., Y.-H.T., O.A., and C.-I.W.; supervision, Y.-C.L. and Y.-H.T.; project administration, Y.-H.T.; funding acquisition, Y.-C.L. and Y.-H.T. All authors have read and agreed to the published version of the manuscript.

Funding: The study was supported by the Ministry of Science and Technology, R.O.C. (Contract No. MOST 106-2221-E-022-017-MY3).

Conflicts of Interest: The authors declare no conflict of interest in the publication of this article.

\section{References}

1. Lehane, L.; Olley, J. Histamine fish poisoning revisited. Int. J. Food Microbiol. 2000, 58, 1-37. [CrossRef]

2. Taylor, S.L. Histamine food poisoning: Toxicology and clinical aspects. Crit. Rev. Toxicol. 1986, 17, 91-128. [CrossRef]

3. van Poelje, P.D.; Snell, E.E. Pyruvoyl-dependent enzymes. Annu. Rev. Biochem. 1990, 59, 29-59. [CrossRef] [PubMed]

4. Kim, S.H.; Price, R.J.; Morrissey, M.T.; Field, K.G.; Wei, C.I.; An, H. Occurrence of histamine-forming bacteria in albacore and histamine accumulation in muscle at ambient temperature. J. Food Sci. 2002, 67, 1515-1521. [CrossRef]

5. Kung, H.F.; Lee, T.M.; Lin, C.S.; Hong, T.Y.; Tsai, Y.H. Polymerase chain reaction for the detection of histamine-producing bacteria isolated from Taiwanese foods. J. Food Drug Anal. 2012, 20, 74-82.

6. Kim, S.H.; Wei, C.I.; Clemens, R.A.; An, H. Histamine accumulation in seafoods and its control to prevent outbreaks of scombroid poisoning. J. Aquat. Food Prod. Technol. 2004, 13, 81-100. [CrossRef]

7. Wang, C.Y.; Huang, H.W.; Hsu, C.P.; Yang, B.B. Recent advances in food processing using high hydrostatic pressure technology. Crit. Rev. Food Sci. Nutr. 2016, 56, 527-540. [CrossRef] [PubMed]

8. Considine, K.M.; Kelly, A.L.; Fitzgerald, G.F.; Hill, C.; Sleator, R.D. High-pressure processing -effects on microbial food safety and food quality. FEMS Microbiol. Lett. 2008, 281, 1-9. [CrossRef]

9. Phuasate, S.; Su, Y.C. Efficacy of low-temperature high hydrostatic pressure processing in inactivating Vibrio parahaemolyticus in culture suspension and oyster homogenate. Int. J. Food Microbiol. 2015, 196, 11-15. [CrossRef]

10. Singh, A.; Ramaswamy, H. Effect of high pressure processing on color and textural properties of eggs. J. Food Res. 2013, 2, 11-24. [CrossRef]

11. Christensen, A.; Hovda, M.B.; Rode, T.M. Quality changes in high pressure processed cod, salmon and mackerel during storage. Food Control. 2017, 72, 90-96. [CrossRef]

12. Teixeira, B.; Fidalgo, L.; Mendes, R.; Costa, G.; Cordeiro, C.; Marques, A.; Saraiva, J.A.; Nunes, M.L. Effect of high pressure processing in the quality of sea bass (Dicentrarchus labrax) fillets: Pressurization rate, pressure level and holding time. Innov. Food Sci. Emerg. Technol. 2014, 22, 31-39. [CrossRef] 
13. Ramaswamy, H.; Zaman, S.U.; Smith, J.P. High pressure destruction kinetics of Escherichia coli (O157:H7) and Listeria monocytogenes (Scott A) in a fish slurry. J. Food Eng. 2008, 87, 99-106. [CrossRef]

14. Wang, C.Y.; Huang, H.W.; Hsu, C.P.; Shyu, Y.T.; Yang, B.B. Inactivation and morphological damage of Vibrio parahaemolyticus treated with high hydrostatic pressure. Food Control 2013, 32, 348-353. [CrossRef]

15. Huang, H.W.; Lung, H.M.; Yang, B.B.; Wang, C.Y. Responses of microorganisms to high hydrostatic pressure processing. Food Control 2014, 40, 250-259. [CrossRef]

16. Tsai, Y.H.; Kung, H.F.; Lee, T.M.; Lin, G.T.; Hwang, D.F. Histamine related hygienic qualities and bacteria found in popular commercial scombroid fish fillets in Taiwan. J. Food Prot. 2004, 67, 407-412. [CrossRef]

17. Hsu, H.H.; Chuang, T.C.; Lin, H.C.; Huang, Y.R.; Lin, C.M.; Kung, H.F.; Tsai, Y.H. Histamine content and histamine-forming bacteria in dried milkfish (Chanos chanos) products. Food Chem. 2009, 114, 933-938. [CrossRef]

18. Smelt, J.; Rijke, G. High pressure treatment as a tool for pasteurization of foods. In High Pressure and Biotechnology; Balny, C., Hayashi, R., Heremans, K., Masson, P., Eds.; Colloque INSERM/John Libbey Eurotex Ltd.: Montrouge, France, 1992; pp. 361-364.

19. Patterson, M.F.; Quinn, M.; Simpson, R.; Gilmour, A. Effects of high pressure on vegetative pathogens. In High Pressure Processing of Foods; Ledward, D.A., Johnston, D.E., Earnshaw, R.G., Eds.; Nottingham University Press: Nottingham, UK, 1995; pp. 47-63.

20. Furukawa, S.; Noma, S.; Shimoda, M.; Hayakawa, I. Effect of initial concentration of bacterial suspensions on their inactivation by high hydrostatic pressure. Int. J. Food Sci. Technol. 2002, 37, 573-577. [CrossRef]

21. Dogan, C.; Erkmen, O. High pressure inactivation kinetics of Listeria monocytogenes inactivation in broth, milk, and peach and orange juices. J. Food Eng. 2004, 62, 47-52. [CrossRef]

22. Tassou, C.; Galiatsatou, P.; Samaras, F.J.; Mallidis, C.G. Inactivation kinetics of a piezotolerant Staphylococcus aureus isolated from high-pressure-treated sliced ham by high pressure in buffer and in a ham model system: Evaluation in selective and non-selective medium. Innov. Food Sci. Emerg. Technol. 2007, 8, 478-484. [CrossRef]

23. Alpas, H.; Kalchayanand, N.; Bozoglu, F.; Ray, B. Interactions of high hydrostatic pressure, pressurization temperature and $\mathrm{pH}$ on death and injury of pressure-resistant and pressure-sensitive strains of foodborne pathogens. Int. J. Food Microbiol. 2000, 60, 33-42. [CrossRef]

24. Hoover, D.G.; Metrick, C.; Papineau, A.M.; Farkas, D.F.; Knorr, D. Biological effects of high hydrostatic pressure on food microorganisms. Food Technol. 1989, 43, 99-107.

25. Simpson, R.K.; Gilmour, A. The effect of high hydrostatic pressure on Listeria monocytogenes in phosphate-buffered saline and model food systems. J. Appl. Microbiol. 1997, 83, 181-188. [CrossRef]

26. Cheftel, J.C.; Culioli, J. Effects of high pressure on meat: A review. Meat Sci. 1997, 46, 211-236. [CrossRef]

27. Panagou, E.Z.; Tassou, C.C.; Manitsa, C.; Mallidis, G. Modelling the effect of high pressure on the inactivation kinetics of a pressure-resistant strain of Pediococcus damnosus in phosphate buffer and gilt-head seabream (Sparus aurata). J. Appl. Microbiol. 2006, 102, 1499-1507. [CrossRef] [PubMed]

28. Patterson, M.F. Microbiology of pressure-treated foods. J. Appl. Microbiol. 2005, 98, 1400-1409. [CrossRef] [PubMed]

29. Pilavtepe-Çelik, M.; Balaban, M.O.; Alpas, H.; Yousef, A.E. Image Analysis based quantification of bacterial volume change with high hydrostatic pressure. J. Food Sci. 2008, 73, 423-429. [CrossRef]

30. Ritz, M.; Tholozan, J.L.; Federighi, M.; Pilet, M.F. Morphological and physiological characterization of Listeria monocytogenes subjected to high hydrostatic pressure. Appl. Environ. Microbiol. 2001, 67, 2240-2247. [CrossRef]

31. Mackey, B.M.; Forestiere, K.; Isaacs, N.S.; Stenning, R.; Brooker, B. The effect of high hydrostatic pressure on Salmonella thompson and Listeria monocytogenes examined by electron microscopy. Lett. Appl. Microbiol. 1994, 19, 429-432. [CrossRef]

32. Marx, G.; Moody, A.; Bermúdez-Aguirre, D. A comparative study on the structure of Saccharomyces cerevisiae under nonthermal technologies: High hydrostatic pressure, pulsed electric fields and thermo-sonication. Int. J. Food Microbiol. 2011, 151, 327-337. [CrossRef]

(C) 2020 by the authors. Licensee MDPI, Basel, Switzerland. This article is an open access article distributed under the terms and conditions of the Creative Commons Attribution (CC BY) license (http://creativecommons.org/licenses/by/4.0/). 